\title{
Remembering To Write: Five Letters to Real Imaginaries...
}

\author{
Carol Laing
}

\section{Se souvenant pour écrire: Cinq lettres à des imaginaires réelles}

Le texte d'une performance, les cinq letters d'amour font témoignage contre l'oubli, comme protestation ou célébration de ce qui a été, pour des raisons diverses, mémorable. A Sandra d'Italie, elle écrit l'amour pour ses mots qui, même en traduction, parlent siéloquement du corps résistant de la femme dans la cité. A Camille Paglia, elle lance le différend, car Camille, l'égomaniaque avouée, une fille à papa, n'aime pas le féminisme (au singulier!) puisque les féministes n'admettent pas la supériorité des hommes. À Elisabeth, elle répond à l'invitation dans (Sem)erotics pour écrire une lettre d'amour exprimant son étonnement et sa reconnaissance pour la publication d'un livre théorique, voire académique, en forme de lettres d'amour lesbiennes. À Rita, elle écrit ses remerciements pour son spectacle d'il y a un an, "In Bocca al Luppo," la plus forte présentation publique du désir féminin. La scène accordait à Rita la permission de gueuler durant dix minutes jusqu'à ce que sa voix s'éteigne. À Leslie, elle écrit au sujet des images provoquées par la mémoire d'une figure dans Nightwood de la peau de la femme marquée par le système social, un tatouage qu'elle reconstruit avec son propre corps marqué par des traces d'ombre d'une dentelle faite par une ancêtre distante, pris en photo pour échanger avec ses interlocutrices dans cette performance.

[A note by way of beginning: or how I really got here, when "here" was still "there"...So Carol, here it is again : the plane leaves in less than 12 hours, and the pieces go on being scattered everywhere, utterly resisting coming together. All the photocopies, and journals; the books, spreadeagled or stacked on the bed, the desk, the floor... The blank blue glare of the computer screen, and its strange hum. The softer sound of rain falling. My back to the wall, knees up, scribbling: the real truth about performing knowledge at the end of this 20th century : all the false starts; 
the familiar sensation of drowning always, in information...The litter before the letter ever arrives...

There are - aren't there always? - precedents for these letters...Without being exhaustive, what comes to mind immediately are the postcards in the film, Sigmund Freud's Dora...or Jane Weinstock's exchanges - in the catalogue Ghost Writer - with Barbara Bloom. There's Natalia Ginzburg's novel in the form of letters, The City And The House...And Jane Gallop's "Annie Leclerc, Writing A Letter With Vermeer"; there's my own love of letters, and how I hardly ever write them anymore...Here, they are a kind of memory work: against forgetting, a deliberate reach, or protest or tribute to what has proved - for different reasons - memorable...]

Dear Sandra,

I don't know who you are, really. I only know your first name. I've never seen your picture. All I know of you is your "Suggestions From Irigaray..." in the Italian Feminisms' reader; the text that begins -

There is a woman's body: a project as well as a starting point. There is a body which tries to move out of the gaze of power in order to articulate its own pleasure. There is a body which seeks a "house of its own"... a body which shouts, which breathes, in the din of the city; there is a body which is forced to function against itself... (that) watches itself living, obeying the rules. There is a woman who goes in and out of the body she inhabits. There is a woman entangled, imprisoned in the order of things; there is a body which resists... (Sandra 177)

I love your words that arrive, even in translation, like the flood of some river...

I don't know if I'll ever meet you, though I know enough Italian that I could speak to you, if I did. But I know I cannot have you: I can only stay near you as you - in language - approach me...And prepare myself to lose you, as we all lose all our lovers...

I've been to Rome, to some of the places that matter to you, too. So, please, take this letter that imagines you; and-some bright midmorning 
there in the Campo dei Fiori - have a cappuccino for both of us... By way of remembering me...

Because your words have fed me, better than bread; that's another Italian expression (though not one I learned from you)...

con tanti cari saluti, Sandra...Ti abbraccio da lontano,

Carol

Dear Camille Paglia. I mean, Dear Ray Conlogue. Or is it Dear Harold Bloom?

Or Dear Sigmund Freud? Maybe it's Dear Ralph (Ralph Waldo Emerson: he of the 19th century "Self- Reliance" renown)...

You don't look like a tow truck. But that's what Ray in The Globe and Mail said you were. The tow truck that was going to pull feminism (it's all simple and singular to Ray) out of the deadend street where he goes on hoping it's become mired... Ray's clearly never read much feminist writing, or it couldn't be all one to him. But he knows what he likes. And he likes you, Camille. You're just like him, after all: nothing worrisome there...You're feisty, and a self-confessed egomaniac. The problem with feminism - it's all one to you, too, Camille - is that all women aren't enough like you: which means eager to admit that it's men who are biologically programmed to be artists (since they can't create babies, right? Is that what you really said?) But you're the exception that proves the rule: the good daughter of the fathers who don't want to be challenged. Which means your ideas are continuous with their power, and privilege. Why they include you, and even welcome you: so long as you don't ask for anything to be different...

I'm sending this letter care of your mentor; you know who I mean, Harold: the lagging romantic hero at the nearend of this second millenium whose agon, and whose agony, have ceased to be either believable, or admirable to many of us, now we know what it costs... Harold will look out for you. You're the only kind of feminist he likes; besides, he's taught you all he knows. Others among us would find it hard, Camille, taking care of you. Not that you want us to. What you say will go on costing us all. Somewhere you know that...If only you had a sense of 
humour, we could laugh...Then this might be over. But this is the 90s: and there's not much relief in sight, comic or otherwise. Everything just keeps coming round again...And yes, your books sure are selling.

Perhaps, with effort, I could learn to think of you as a towtruck...No, the hook's not there for me: it's too ludicrous to try to imagine you as some rescuer.

In the end, for me, the irony is that you're so alone. I know that's why you try so hard. That's where the poignancy is: you out there, performing...throwing their voices, like an echo. If you stopped repeating what it is they say, they wouldn't listen to you any more. I wish this weren't so. But you seem to thrive on the attention...

Yours, across difference, Carol

\section{Dear Elizabeth,}

I have to admit: your book took me by surprise. All those loveletters, there in academia. And lesbian loveletters, too. Even you admit, you waited till you got tenure before publishing this text. So that's what tenure is for. There's something hopeful about that...And something much more affecting than anything Paglia's said. For your passion is embodied, and brave. It is your own. It reminds me of Muriel Rukeyser's (though her passion didn't keep all her books from going out of print soon after she died). Those are the risks, and Rukeyser knew that. Why I'll end with her. Bring her back with a fragment of a poem I know will be reissued. Because it's true, and we need to be reminded of what she says:

To be a jew in the twentieth century

Is to be offered a gift. If you refuse,

Wishing to be invisible, you choose

Death of the spirit, the stone insanity.

Accepting, take full life...

We can go back, I think, to the first line of Rukeyser's poem. We can substitute for jew, the lesbian Rukeyser also was. We can substitute other people who've been Othered. On the margins that go on being too common to too many of us. The margins that still mean exclusion. It is 
reason enough - and there is work enough - for all of us who find ourselves still there to go on performing...According to our own strengths. According to our own desires, and needs. According to the particularities of our own experience...Performing knowledge...

At the end of your book, Elizabeth, you published a letter a reader had sent you. You speculated that if enough people sent you letters, they might fill a (next) book. So here's a letter for you. I may write again. You said love letters would be nice...

I hope you get a bookfull. Thanks for (Sem)erotics...for helping to publicly imagine us,

Write back; all the best,

Carol

[Aside \#2 : and why I decided not to stop here...

It's five in the morning, and I'm already awake. I turn off the fan whose rattle I blame for this too early return to consciousness... Blame the fan. Or this dryness in my mouth. Blame how I miss my own bed (though I seem to have two these days). More likely, it's nerves that brought me back. I feel my blood run... And now I know I'm awake because I'm not satisfied: can't stay here calmly in the dark, on my side, with the spread palm of one hand laid warmly across the ripple of my ribs...I'm awake because I want to change things (it's only deadlines, it seems, that give a final shape to what I do. That decide where I stop). I want to cut the first aside: add more letters... There are other things I want to try to say...

So, four hours before speaking, here I am again: back to the headboard, knees up, scribbling... Here in this irregular room, full of acid greens and bright oranges. The pattern of brown burled pecan; in laminate, of course. The black TV is hinged to the wall and angled, trained heartlessly on me like a blind rectangular eye. For reassurance, I glance to the right, and thankfully they're still there: my bedside books...I touch the cover of Colette's The Pure and The Impure...run a finger down the spine of Dacia Maraini's Letters to Marina...In the lamplight, they're warm to the touch...

Lifelines...

The minutes tick away...I scribble...Scribble...] 
Dear Rita,

It's been about a year...almost exactly a year...since my lover and I perched precariously on books in that unheated space you'd rented down on River St...There, in the darkness and the damp, we saw your first opera, In Bocca AlLupo... In the Mouth OfThe Wolf... You and I haven't met since, though we've talked on the phone. I've heard you're in Calgary now...

What an amazing performance that was: your actors, all women. Their images have stayed with me. I can sometimes still feel their presence: anxious, angry, frenetic, insistent...Restless. Moving; moving...It's been the strongest public presence I've seen yet of a staged female desire. I saw that night a Rita I'd never seen before. A Rita who stepped out of the soft and endlessly kind way you always have with others; you ranted there, for ten minutes, until your voice broke. I guess the stage gave you that permission.

Before your rant, there'd been a duet. Between the awesome Dangerous Animal and Celina, the lead singer in Mother Tongue... They circled round, glancing off each other until they stood finally face to face, their gazes locked, the Dangerous Animal's fierce prowl tamed; Celina was stunning and quiet in a shimmering scarlet slip, her black head shaved. The charge between them was thrilling, like a doubled heartbeat...

Later that evening, in a café on Roncesvalles, the Dangerous Animalout of costume now, as was her lover Kim - came over to our table, to say hello. She had the gentlest voice I think I've ever heard. I don't know why I was surprised.

Can't wait to hear what you're doing now in Calgary. I hope our paths cross again soon,

love,

Carol

Dear Leslie,

No, I hadn't planned to use images at all. But there was a figure in language that has stayed with me: it was directed to Djuna Barnes's Nightwood, to how -in her writing - the effects of the social conditioning 
of women surface not only in behaviours, but also emblematically: as if the invisible pressures left visible markings on the female body itself: like, tattoos...

It's a description that's haunted me. And it's led to this image of a patterned female body that'll appear - doubled, as a pair - in my next exhibition. It's an arm's length polaroid. A torso. My own, taken against my kitchen wall in South Bay. In early morning light.

I just put myself into the picture that, for a year and a half, has been there when the sun rises: a constantly shifting projection of the pattern of a piece of lace made by a female relative whose name I'll never know. It came into my hands when my father died. Now I use it as a curtain for my kitchen door. Anyway, I wanted to give you this colour copy of it. It's the only thing my performance will leave behind. I thought I'd pass it around first before I give it to you: to let something material change hands.

I really like that we're all trying to do this panel thing differently. Thanks for asking me to be with you. I'll try not to flop. See you in two hours,

Nervously,

Carol

\section{Works Cited}

Conlogue, Ray. The Globe and Mail 5 Nov. 1992: C1.

Sandra. "Suggestions from Irigaray." Italian Feminist Thought. A Reader.

Ed. P. Bono and S. Kemp. London: Basil Blackwell, 1991.

Marcus, Jane. "Laughing at Leviticus: Nightwood as Woman's Circus

Epic." Silence and Power. Ed. Mary Lynn Broe. Carbondale, IL: Southern Illinois UP, 1991.

Meese, Elizabeth A. (Sem)erotics. Theorizing Lesbian Writing. New York: New York UP, 1992.

This text is an edited excerpt from a performance that was prepared for the University Art Association panel, "Performing Knowledge: Strategies for Staging the Visual Arts" (Victoria, 1992). 


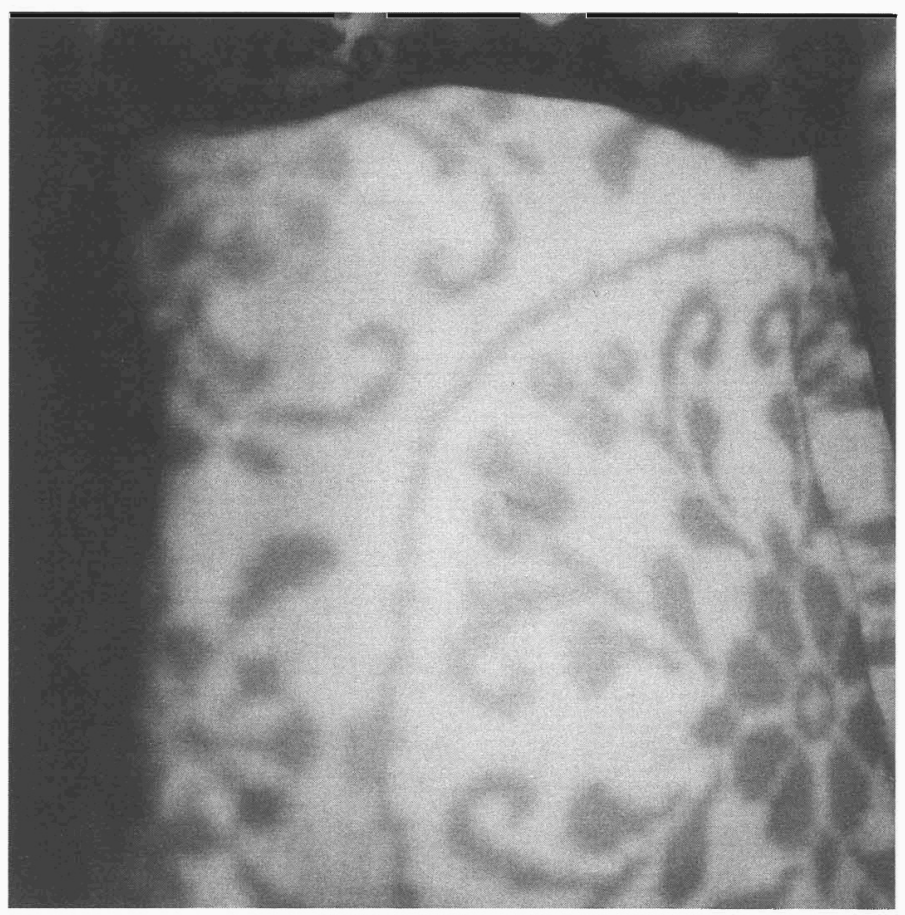

